Marquette University

e-Publications@Marquette

Economics Faculty Research and Publications

Economics, Department of

$2-1-2018$

Free Trade Agreements and Volatility of Stock Returns and Exchange Rates: Evidence from NAFTA

Bram Daelemans

Marquette University

Joseph P. Daniels

Marquette University, joseph.daniels@marquette.edu

Farrokh Nourzad

Marquette University, farrokh.nourzad@marquette.edu

Accepted version. Open Economies Review, Vol. 29, No. 1 (February 2018): 141-163. DOI. (C) 2018 Springer. Used with permission. 


\title{
Free Trade Agreements and Volatility of Stock Returns and Exchange Rates: Evidence from NAFTA
}

\author{
Bram Daelemans \\ Research Associate \\ Center for Global and Economic Studies, Marquette University \\ and Wisconsin Angel Network, Madison WI 53711 \\ Joseph P. Daniels \\ Professor, Economics Department \\ Marquette University, College of Business Administration \\ P.O. Boz 1881, Milwaukee, WI 53201-1881 \\ joseph.daniels@mu.edu \\ Farrokh Nourzad ${ }^{1}$ \\ Professor, Economics Department \\ Marquette University, College of Business Administration \\ P.O. Boz 1881, Milwaukee, WI 53201-1881 \\ farrokh.nourzad@mu.edu
}

Keywords: Free Trade Agreement, NAFTA, volatility

JEL Codes: F13, F14

\begin{abstract}
$^{2}$
This paper uses GARCH models and daily data to investigate the effect of the Canada - U.S. Free Trade Agreement (CUSFTA) and NAFTA on the volatility of, and the relationship between stock market returns and changes in bilateral exchange rates of the member countries. Empirical results indicate that the CUSFTA had a stabilizing effect on the Canadian and U.S. equity markets while increasing the volatility of the CAD/USD exchange rate. NAFTA further reduced the two stock markets' volatility, however unlike CUSFTA, NAFTA also reduced the volatility of the CAD/USD exchange rate. Additional results indicate that during NAFTA, the Mexican stock market is more volatile than the other stock and bilateral exchange markets. Moreover, the exchange rate of the Mexican peso against both the U.S. and Canadian dollars has been more volatile than the Canadian dollar/US dollar exchange rate. Evidence also suggests that all three stock markets are positively correlated with each other with the U.S. market being much less correlated with the Canadian and Mexican stock markets than the latter two markets are correlated with each other. Evidence found in this paper suggests a negative relationship between the stock and bilateral currency markets that is statistically significant except for the U.S. equity market when paired with an exchange rate that involves the Mexican peso.

${ }^{1}$ Corresponding author.

${ }^{2}$ We thank two anonymous referees for offering valuable suggestions.
\end{abstract}




\title{
Free Trade Agreements and Volatility of Stock Returns and Exchange Rates: Evidence from NAFTA
}

\begin{abstract}
This paper uses GARCH models and daily data to investigate the effect of the Canada - U.S. Free Trade Agreement (CUSFTA) and NAFTA on the volatility of, and the relationship between stock market returns and changes in bilateral exchange rates of the member countries. Empirical results indicate that the CUSFTA had a stabilizing effect on the Canadian and U.S. equity markets while increasing the volatility of the CAD/USD exchange rate. NAFTA further reduced the two stock markets' volatility, however unlike CUSFTA, NAFTA also reduced the volatility of the CAD/USD exchange rate. Additional results indicate that during NAFTA, the Mexican stock market is more volatile than the other stock and bilateral exchange markets. Moreover, the exchange rate of the Mexican peso against both the U.S. and Canadian dollars has been more volatile than the Canadian dollar/US dollar exchange rate. Evidence also suggests that all three stock markets are positively correlated with each other with the U.S. market being much less correlated with the Canadian and Mexican stock markets than the latter two markets are correlated with each other. Evidence found in this paper suggests a negative relationship between the stock and bilateral currency markets that is statistically significant except for the U.S. equity market when paired with an exchange rate that involves the Mexican peso.
\end{abstract}

\section{Introduction}

Until 2012, most free trade agreements (FTA) incorporated treaties designed to encourage cross-border capital flows. The economic rationale was that capital market liberalization, along with open trade, would lead to an optimal allocation of scarce productive resources. A problem, however, is that financial market liberalization often precedes a financial crisis (Reinhart and Rogoff 2009). In 2012, the International Monetary Fund adopted a new position that trade and investment treaties should have some safeguard controls on capital to stem large and disruptive flows. Agreements in which the United States is a party, however, still tend to minimize or restrict any capital controls, although U.S. policymakers did agree to relatively weak safeguards when negotiating NAFTA (Gallagher, Anderson, and Viterbo 2013). The question, therefore, is whether FTAs with relatively weak financial safeguards, such as NAFTA, impact the volatility of key financial variables. 
Trade agreements, independent of investment treaties, may affect key higher-frequency variables such as exchange rates and stock market returns between member countries through a real sector channel (current account effects resulting from increased trade opportunities and greater competition, for example). When accompanied by investment agreements that liberalize or encourage capital flows such as the Canada-U.S. FTA and NAFTA, for example, they also may spur greater capital flows and thereby impact exchange rates and stock market returns through a financial market channel.

On a longer-run basis, trade agreements may incentivize firms to move production abroad in the form of FDI (Feinberg and Keane 2001) and alter the composition from shorterterm flows to longer-term flows, which tend to be more stabilizing (Kim, Kim, and Wang, 2004). Furthermore, complementary investment and tax treaties may also lead to shifts in how firms finance FDI among the three modes of financing namely retained earnings, equity capital, and inter-company debt (Daniels, O’Brien, and von der Ruhr, 2015). Trade agreements such as NAFTA that are accompanied by investment treaties that limit the use of policy tools to stem capital flows, therefore, can impact both trade and capital and investment flows thereby affecting the volatility of key macroeconomic variables such as exchange rates and stock returns.

There is an extensive empirical literature on the economic consequences of free trade agreements including studies about the impact of these agreements on international trade flows (e.g., Baier and Bergstrand 2009, Calvo-Pardo, Freund, and Ornelas 2009), their effect on currency markets (e.g., Krishnapilla and Thompson 2011, Marmolejo 2011, Hogan and Sultan 1994), and their effect on equity markets (e.g., Ewing, Payne, and Sowell 2001, 1999, Aggerwal and Kyaw 
2005, Darrat and Zhong 2005, and Nezerwe 2014). A separate issue that has been researched widely is the relationship between exchange rates and returns in stock markets (e.g., Mun 2007, Du and Hu 2012a, 2012b, Walid, Chaker, Masood, and Fry 2011, Eissa, Chortareas, and Cipollini 2010).

Our interest is whether a policy such as a trade agreement, which boosts bilateral trade and capital flows, creates conditions that affect volatility in the equity and foreign exchange markets. We begin by considering the impacts of NAFTA using a multivariate GARCH model and daily data to estimate conditional variances of stock returns and changes in bilateral exchange rates in Canada, Mexico, and the United States. We also estimate conditional correlations between stock returns of these countries as well as between stock returns and changes in bilateral exchange rates.

Further, we test whether the conditional correlations are constant and estimate dynamic conditional correlations when conditional correlations are found to be time variant. We then repeat this exercise for CUSFTA and compare the results with those of NAFTA. Hence, what differentiates the work here is that we consider three episodes; before the implementation of a FTA, during a FTA between two advanced economies, and during a FTA that includes two advanced economies and an emerging economy, with the latter being the most notable contribution. Moreover, we also examine the effect of a FTA on different equity markets and the relationships among pairs of equity markets. Finally, we estimate not only constant conditional correlations but also dynamic conditional correlations.

Our empirical results indicate that: (1) CUSFTA, which preceded NAFTA, had a stabilizing effect on the Canadian and U.S. equity markets, but led to increased volatility of the CAD/USD 
exchange rate. (2) The implementation of NAFTA further reduced the Canadian and U.S. stock markets' volatility relative to CUSFTA, but unlike CUSFTA it also reduced the volatility of the CAD/USD exchange rate. Additional findings suggest that: (3) During NAFTA, the Mexican equity returns and bilateral exchange rates markets have been more volatile than the Canadian and U.S. equity returns and bilateral exchange rate, and (4) the exchange rates of the Mexican peso with the Canadian dollar and with the U.S. dollar have been more volatile than the Canadian dollar/U.S. dollar exchange rate. Taken together, the empirical evidence presented in this paper suggest that free trade agreements have the potential of reducing the volatility of members countries' financial markets.

Section 2 provides a brief history of CUSFTA and NAFTA. Section 3 reviews previous theoretical and empirical work on this topic. Section 4 describes the empirical methodology employed in this paper. Section 5 presents and discusses the results for NAFTA while Section 6 compares the effect of NAFTA with CUSFTA. Section 7 summarizes main findings of this study and offers a conclusion.

\section{Brief History of Canada-U.S. and North America Free Trade Agreements}

The Canada - U.S. Free Trade Agreement was the predecessor of North America Free Trade Agreement. CUSFTA negotiations between Canada and the U.S. began in 1986 with the Canadian team led by former Deputy Minister of Finance, Simon Reisman and the American side by Peter O. Murphy, the former deputy United States trade representative in Geneva. An agreement was reached on October 4, 1987. 
Canada desired unhindered access to the American economy and, the United States, in turn, wished to have access to Canada's energy and cultural industries. As stated in the agreement, the primary purposes of the CUSFTA were to (US and Canadian Governments, 1988): eliminate barriers to trade in goods and services between Canada and the United States; facilitate conditions of fair competition within the free-trade area established by the Agreement; significantly liberalize conditions for investment within that free-trade zone; establish effective procedures for joint administration of the Agreement and resolution of disputes; and lay the foundation for further bilateral and multilateral cooperation to expand and enhance the benefits of the Agreement. The Agreement phased out a wide range of trade restrictions in stages over a ten-year period and resulted in a significant increase in cross-border trade.

With the addition of Mexico on January 1, 1994, CUSFTA was replaced by NAFTA. Mexican policymakers primarily saw NAFTA as a means to attract greater capital inflows and, so it was they who originally proposed the idea of a NAFTA in the mid-1980s (Arndt 1996). Though U.S. policymakers were "unusually receptive" (Arndt, p. 78), the Canadians were not. Nonetheless, the Canadians wanted to maintain the gains from the CUSFTA and negotiate the new rules of origin. Diplomatic discussions among the three nations date back to 1986 with formal negotiations starting in 1991 and the leaders of the countries signed the FTA agreement on December 17, 1992. The NAFTA partners also negotiated two side agreements: The North American Agreement on Environmental Cooperation (NAAEC) and the North American Agreement on Labor Cooperation (NAALC) (Office of the United States Trade Representative).

NAFTA created the world's largest free trade zone. It linked together more than 475 million people producing $\$ 20$ trillion worth of goods and services. The agreement 
systematically eliminated most tariff and non-tariff barriers to trade and facilitated crossborder capital flows. NAFTA also provided protection for cross-border investments, protection for intellectual property, easier access for business travelers, and equal access to government procurement.

By establishing a stable and reliable framework for investment, NAFTA has also helped create the environment of confidence and stability required for long-term investment, a key motivation for Mexico (Arndt 1996). However, Mexico entered the agreement in 1994 with some of the same problems that preceded its debt crisis of 1982 . That is, an excess reliance on international debt rather than direct investment. Mexico also differed from the U.S. and Canada in that the exchange rate was relatively rigid and managed through a crawling-peg arrangement.

The entry year was also ill-timed due to events beyond the control of Mexican policymakers (see Klein and Coutiño 1996 for an interesting account). This was an election year for Mexico and it started with the Chiapas rebellion in the south. Next, the U.S. Federal Reserve began rising the federal funds rate, for the first time in five years, on February 4 by 25 basis points (and eventually increased the rate by 250 basis points by year end). Shortly thereafter, in March, the leading presidential candidate Colosio was assassinated. As put by Klein and Coutiño, this troubled international investors and started a massive exodus of capital. In December 1994 a crisis took hold, resulting in a significant currency depreciation, higher interest rates and inflation, and a deep recession in 1995. It should be noted that policymakers also implemented limited capital controls during the crisis. These events are important to the empirical work here, and controlled for in our models that follow. 


\section{Previous Theoretical and Empirical Work}

\section{a. Theoretical Literature}

The theoretical motivation for our empirical works rest primarily on the literature linking trade openness, current and capital account integration, exchange rates, and stock market returns. The existing literature on trade openness can be synthesized into two channels; a real sector channel and a financial sector channel (Hau 2002, Phengpis and Swanson 2006, Basu and Morey 2005, and Ewing, Pyane and Sowell 2001). Through the real sector channel, deepening trade integration offers firms increased market access as well as greater competition, thereby affecting the level and variability of the exchange rate. Indirectly, increased scale and competition as well as exchange rate changes affect firm profitability and, therefore stock market returns (Kennedy and Nourzad 2016).

Considering specifically the potential of NAFTA, Manchester and McKibbin (1995) argue that most studies focus only on the direct effects of trade flows and overlook the dynamic role of resulting capital flows. They employ a computable general equilibrium model and allowing for physical capital flows to respond to changes in factor productivity. They assert that these flows affect risk premiums and exchange rates and that, though likely to primarily benefit Mexico, also provide gains to the NAFTA partners and the rest of the world.

In a three-country theoretical model, Peter (2012) shows that, though they have independent effects, overall trade openness as well as increased bilateral trade lead to greater bilateral asset holdings. Specifically, Peter shows that holding overall trade openness constant, increased bilateral trade increase cross-border asset holdings, while holding bilateral trade constant increase trade openness can increase bilateral asset holdings through terms of trade 
effects, and that higher degrees of trade openness dampen the impact of increased bilateral trade on bilateral asset holdings.

Trade agreements are typically accompanied by increased capital market integration (which was the case for NAFTA, especially for Mexico, see in particular, Ewing, Payne, and Sowell 2001). Hence, through the financial sector channel, the accompanying capital account liberalization leads to increased cross-border capital flows and potentially stock market volatility but also expanded opportunities for broader portfolio diversification and risk mitigation. Hence, the real sector channel affects stock market returns rather indirectly through exchange rate and competition effects. Financial market integration, in contrast, more directly affects stock market returns through capital flows (Ewin, Payne and Sowell 1999, Taylor and Tonks 1989).

This literature leads us to conclude that, given that Canada and the U.S. had already been engaged in a FTA and had a tax and investment treaty dating back to 1940 (and updated prior to the CUSFTA), these countries were well positioned for increased direct investment flows. Hence, the primary effects of expanding the FTA on Canada and the United States would likely be through the financial channel and the rather stabilizing effect of long-term capital flows. Arndt argues that, though most people saw the NAFTA as a trade agreement, Mexican policymakers saw it as an opportunity to attract foreign investment. Through the real sector channel, increased trade would likely depreciate the Mexican peso, a desirable effect. Through the financial channel, however, increased capital flows would appreciate the peso. He claims that up to the crisis of 1994-1994, Mexican policies had not balanced the tension between these two effects. 


\section{b. Empirical Literature on FTAs and Equity and Foreign Exchange Markets}

There is a large body of empirical literature on the economic consequences of free trade agreements including studies about the impact of these agreements on international trade flows and equity and foreign exchange markets. Hogan and Sultan (1994) investigate the effect of news about the implementation of the Canada-U.S. Free Trade Agreement and find that information suggesting an increase in the likelihood of FTA diminished exchange rate volatility. Hanson and Song (1998) consider the responses of the U.S. and Mexican stock markets to the announcement that NAFTA had been agreed upon and find no significant effect on the returns to investing in the U.S. firms, while the effect on the Mexican stock returns is positive.

Aggarwal (1998) studies the impact of NAFTA on the valuation of U.S. companies covering various industries traded on the U.S. stock market and finds that some industries that were predicted to benefit from NAFTA experienced stock price declines at the signing of the treaty. Nezerwe (2014) investigates the effect of the Southern African Development Community Free Trade Agreement on South Africa stock returns and finds that the free trade area had a positive impact on profits in South Africa. Darrat and Zhong (2005) support Nezerwe's conclusion as they find evidence of intensified equity market linkage since the NAFTA accord. Darrat and Zhong suggest that the primary reason behind the stronger capital market linkage is interdependent goods markets in the region. Aggarwal and Kyaw (2005) find the U.S. stock prices to be more integrated with both the Canadian and Mexican stock prices after the passage of NAFTA. Rodriguez (2003) and Thompson (1994) analyze the impact of NAFTA and the Canada-U.S. Free Trade Agreement on stock returns in the U.S. and Canada. Unlike other studies, their results do not suggest a direct relationship between trade 
liberalization and returns.

\section{c. Empirical Literature on Exchange Rates and Stock Prices}

The relationship between exchange rates and stock prices is of great interest to both professionals and academics. There is a clear evolution in the methods used to analyze this relationship. The earliest studies focus on the correlation or visual inspection of the data between an exchange rate index and a stock price index for a single country, while others examine the two variables using cross-country data. Later studies investigating the causality between exchange rates and stock returns do not seem to agree as to the direction in which causality flows. Some studies find evidence of stock prices affecting the exchange rate while others conclude that the fluctuations in the exchange rate have a causal effect on stock market returns. Other studies find that the causality changes direction over time, or that there is causality in both directions, even that no causality exists between these two variables at all. Most recent studies employ generalized autoregressive conditional heteroscedasticity (GARCH) models to investigate the relationship.

The CXO Advisory Group, a private research institution in the United States, performed a visual inspection of the daily movement of the dollar/euro exchange rate and the S\&P 500 index over the period from January 2000 through September 2009. They find that exchange rates and market returns sometimes move together and other times move in opposite directions from each other. Using an error correction model (ECM), Ajayi and Mougoué (1996) simultaneously estimate the short- and long-run dynamic relationships between stock indices and exchange rates. They find that a decrease in stock prices causes the home currency to appreciate in the short run. Over the long term, however, declines in stock prices hurt domestic 
currency value, while currency appreciations have positive short- and long-run effects on stock prices.

Bodart and Reding (1999) find evidence that an increase in exchange rate volatility is associated with a decline in dynamic international correlations between stock markets but they do not detect a marked linkage between the patterns of volatilities on the stock exchange and the foreign exchange market. Nieh and Lee (2001) investigate the dynamic relationship between stock prices and exchange rates for the G-7 countries using an ECM model. They find no significant association between the two variables, which is similar to the finding by BahmaniOskooee and Sohrabian (1992) that no co-movement between stock prices and exchange rates exists. In contrast, the studies by Kanas (2002) and Yang and Doong (2004) conclude that for the G-7 countries, in general, the movements of stock prices spills over to the foreign exchange market but that the volatility spillovers from exchange rates have a less significant impact on stock prices.

Tabak (2006) focuses on the Brazilian economy and finds no long-run relationship between equity and currency markets, but finds evidence of linear Granger causality from stock prices to exchange rates. He concludes that this is in line with the portfolio theory that stock prices lead exchange rates with a negative correlation. Tabak also finds that there is nonlinear Granger causality from exchange rates to stock prices with exchange rates leading stock prices. Zhao (2010) analyzes the dynamic relationship between the two markets for China using VAR and multivariate GARCH models. He finds no evidence of a stable long-run equilibrium relationship between the Renminbi real effective exchange rate and stock prices and no evidence of mean spillovers between the two markets. However, Zhao finds bi-directional 
volatility spillovers between the equity and foreign exchange markets.

\section{d. Empirical Relationship between International Stock Markets}

The increase in international financial integration has received growing attention over the years and has led to several studies on the relationship between stock prices and returns of different countries. Various factors such as geographic location and timing of trading seem to influence the relationship between different countries' equity markets.

Hamao et al. (1990) study the short-term transmission of the effect of price changes and price volatility from one international stock market to another in three countries: Japan, the U.K., and the United States. Based on estimates of conditional variance, the authors find evidence of price volatility spillovers from the New York Stock Exchange to the Tokyo Exchange, from London to Tokyo, and from New York to London. However, they find no evidence of price volatility spillover effects in the other directions. An explanation offered by the authors is the overlapping trading time between New York and London stock markets.

Lee (2009) examines the volatility spillover among stock markets in six Asian countries and the United States before and after the 1997 Asian financial crisis. The results show evidence of statistically significant spillover effects before the financial crisis that drastically increased after 1997. They find that the spillover effect was the largest among the countries that are regionally the closest to each other. Despite the geographical distance of the U.S. to the Asian countries, the influence of the U.S. market on the Asian markets is found to be quite substantial.

Hutchinson and Nourzad (2004) use a vector autoregressive (VAR) model to study the interaction between equity markets of six countries and conclude that the U.S. market has the 
largest impact on the other five national markets. Their results also suggest that the 1997 Asian financial crisis increased the importance of Asian markets to other nations' stock markets.

Eun and Shim (1989) investigate the relationship among major national equity markets with an emphasis on how the impact of innovations in one market is transmitted to other markets. Taking into consideration time zone differences and nonsynchronous character of observations, they find evidence that there is interdependence among national stock markets. Eun and Sim also find the U.S. to have the most influential stock market, a result that is consistent with the finding by Hamao et al., Lee, and Hutchinson and Nourzad.

Panton et al. (1976) analyze co-movement of rates of return in twelve international equity markets and find that there appears to be a core of global stock markets that have higher degrees of similarity between them (e.g., the United States and Canada) than other markets (e.g., Germany and the Netherlands). The authors find a strong tie between the Canadian and U.S. markets that is not only well-developed but is also open to international capital flows.

To summarize, while there is an extensive literature on the impact of free-trade agreements, only a few studies consider the effect on exchange rates. In contrast, there are many studies of the impact of FTA on the securities market, but their findings vary considerably. The relationship between exchange rates and stock returns is also investigated widely but, once again, the results are not conclusive. Thus, further analysis of the effect of FTA on equity and currency markets and the relationship between these two markets is warranted. The one conclusion that can be discerned from the literature is that we should expect a close relationship between the Canadian and the U.S. equity markets due in part to their geographic 
proximity and overlapping trading times (both exchanges, the NYSE and the TSX, open at 9:30 a.m. and close at 4:00 p.m. eastern). The next section provides a description of the empirical approach we use to study these issues.

\section{Estimation Methodology}

Our study of the impacts of NAFTA and CUSFTA utilizes versions of the Generalized Autoregressive Conditional Heteroscedasticity (GARCH) model. The simplest GARCH model is the univariate $\operatorname{GARCH}(1,1)$ model due to Bollerslev (1986). It consists of two related equations, one specifying the conditional mean of a time series and the other expressing its conditional variance as a function of lagged squared residuals from the mean equation and lagged conditional variance:

$$
\begin{array}{ll}
\text { Mean Equation: } & Y_{t}=\beta_{0}+\beta_{1} X_{1 t}+\beta_{2} X_{2 t}+\ldots+\beta_{k} X_{k t}+u_{t} \\
\text { Variance Equation: } & h_{t}=\alpha_{0}+\alpha_{1} u_{t-1}^{2}+\alpha_{2} h_{t-1}+v_{t}
\end{array}
$$

Here, $X_{i t}(i=1,2, \ldots, k)$ represent determinants of conditional mean of $Y_{t}, h_{t}$ is the conditional variance of $Y_{t}$, and $u_{t}$ and $v_{t}$ are random error terms.

Several extensions of the basic GARCH model have been developed including exponential GARCH (EGARCH), integrated GARCH (IGARCH), and GARCH in Mean (GARCH-M) models to name a few. Another extension of the basic model includes multivariate GARCH models such as the VECH (Bollerslev, Engle, and Woodridge 1988) and BEKK (Engle and Kroner 1995) models. A version of the multivariate GARCH model is the Constant Conditional Correlation model described below (Bollerslev 1990).

Consider the following $2 \times 2$ conditional variance/covariance matrix associated with two different time series, $Y_{1 t}$ and $Y_{2 t}$ : 


$$
H_{t}=\left(\begin{array}{ll}
h_{11 t} & h_{12 t} \\
h_{21 t} & h_{22 t}
\end{array}\right)
$$

Given that this matrix is symmetrical, it may be written as a column vector:

$$
\left(\begin{array}{l}
h_{11 t} \\
h_{22 t} \\
h_{12 t}
\end{array}\right)
$$

Here, $h_{i i t}$ is the conditional variance of $Y_{i t}$ and $h_{i j t}$ is the conditional covariance of $Y_{i t}$ and $Y_{j t}, i \neq$ j:

$$
\begin{gathered}
h_{11 t}=\delta_{0}+\delta_{1} u_{1 t-1}^{2}+\delta_{2} h_{11 t-1} \\
h_{22 t}=\gamma_{0}+\gamma_{1} u_{2 t-1}^{2}+\gamma_{2} h_{22 t-1} \\
h_{12 t}=\varphi_{0}+\varphi_{1} u_{1 t-1} u_{2 t-1}+\varphi_{2} h_{12 t-1}
\end{gathered}
$$

We use daily data to estimate equations (1) - (5) for the Canadian, Mexican, and U.S. stock returns and changes in the three countries' bilateral exchange rates. The results are presented and discussed in the following sections.

\section{Estimates of the Effects of NAFTA}

For the U.S., we use the S\&P 500 stock price index, which is based on the market capitalizations of 500 large companies that have common shares traded on the NYSE or NASDAQ. For Canada, we use the S\&P/TSX composite index for the Canadian, which is an index of the equity prices of the 250 largest companies traded on the Toronto Stock Exchange. For Mexico, we use the MexBol for Mexico, a capitalization weighted index of the 20-25 leading stocks traded on the 
Mexican Stock Exchange. These price indices, as well as bilateral exchange rate data, are retrieved from Bloomberg.

We convert each stock price index into continuously compounded daily returns and express bilateral exchange rates as the rate of change from the previous day. We use the resulting series to estimate Equations (1) through (5) above over the period from January 3, 1994, when CUSFTA was extended to include Mexico and became NAFTA, through July 22, 2014.

The descriptive statistics in Table 1 show that over the sample period, Mexico has had the highest average stock market return. Based on the standard deviations representing historical volatility, the U.S. and Canadian equity markets have experienced relatively equal volatility while the Mexican market has faced greater volatility than the other two markets. Regarding bilateral exchange rates, the results in the lower portion of Table 1 suggest that, on average, the Mexican peso (MXN) has depreciated against the Canadian dollar (CAD) as well as the U.S. dollar (USD), and the U.S. dollar has depreciated against the Canadian dollar in this period. What is more, the MXN/CAD and MXN/USD exchange rates have been much more volatile than the CAD/USD exchange rate.

While descriptive statistics are useful for drawing a static and unconditional picture of the equity and foreign exchange markets, they miss the evolution of the time series and fail to consider past shocks and volatilities. GARCH models, to which we turn next, are designed to remedy these shortcomings.

\section{a. Estimates of Conditional Variance}


We begin with estimates of conditional mean equations for the six variables (three stock returns and changes in three bilateral exchange rates). ${ }^{3}$ Each mean equation includes a constant term and dummy variables for the recessions that took place during the sample period in the three member countries. ${ }^{4,5}$ Consider the averages of estimated conditional variances of returns to investing in the Canadian, American, and Mexican stock markets and changes in the bilateral exchange rates found in Table 2. As these figures reveal, the volatility of stock returns in Canada is slightly less than the volatility of returns in the U.S., and both markets are much less volatile than the Mexican stock market. Regarding average volatility estimates for the three bilateral exchange rates in the lower portion of Table 2, we observe that the Canadian dollar/U.S. dollar exchange rate has experienced much less volatility than the MXN/CAD and MXN/USD exchange rates. These results are consistent with those of descriptive statistics described earlier. The plots of estimated conditional variances are shown in Figures 1 and 2.

\section{b. Estimates of Conditional Correlations}

\footnotetext{
${ }^{3}$ All equations are estimated using the t-distribution that has fatter tails than the normal distribution.

${ }^{4}$ Ideally, one should include in the mean equation such macroeconomic variables as real GDP, inflation, energy prices, etc. However, the fact that we use daily data precludes the use of such variables as they are expressed in lower frequencies than daily.

${ }^{5}$ According to the NBER, the U.S. economy has experienced two recessions during the NAFTA period: March 2001 - November 2001, and December 2007 - June 2009. The C.D. Howe Institute reports a single recession for Canada during this period: October 2008 - May 2009. The OECD recession indicators report a total of five recessions for Mexico since it joined NAFTA: September 1994 - August 1995, March 1998 - June 1999, August 2000 - August 2003, January 2008 - May 2009, and August 2012 January 2014. In the case of Mexico, we also controlled for assassination of Luis Donaldo ColosioMurrieta on March 23, 1994 and devaluation of Mexican peso on December 20, 1994 and found the estimation results to be robust to these events. This is perhaps due, at least in part, to the overlap of these events with Mexico's 1994-1995 recession variable.
} 
Having discussed the estimated conditional variances, we now consider the estimates of conditional correlations between pairs of the six series. Table 3 contains estimates of the correlations between the U.S. stock returns and Canadian stock returns $\left(\rho_{12}\right)$, the U.S. equity returns and Mexican stock returns $\left(\rho_{13}\right)$, and the Canadian stock returns and Mexican stock returns $\left(\rho_{23}\right)$. The results show that all three conditional correlations are positive and statistically significant at the $1 \%$ level suggesting that there are co-movements among the three markets. It is interesting to note that the Canadian and Mexican stock markets are more closely related to each other $\left(\rho_{23}\right)$ than they are correlated with the U.S. stock market ( $\rho_{12}$ and $\left.\rho_{13}\right)$ suggesting that shocks originating in either of the former two markets spill over considerably into the other market. This result implies that the U.S. market is somewhat insulated from shocks coming from the Canadian and Mexican markets, which makes sense given that the U.S. market is by far the largest of the three markets.

Table 4 reports the estimated conditional correlations between the returns to investing in stock markets of member countries and changes in their bilateral exchange rates. The results in column (1) indicate that the estimated conditional correlations between the rate of change of the CAD/USD exchange rate and returns to investing in each of the three stock markets are negative and statistically significant. Note that the correlation between the CAD/USD exchange rate and the U.S. stock returns $(-0.044)$ is smaller in absolute value than the other two correlation coefficients. This suggests that shocks to either the CAD/USD or the U.S. stock market would have a lower impact on the other market compared to the Mexican and Canadian currency and equity markets. These results also hold for the correlation between the changes in the MXN/USD and MXN/CAD exchange rates (columns 2 and 3 ) although the 
estimated correlations with the U.S. stock market are not statistically significant. Note that estimated correlations between the Canadian stock returns and each bilateral exchange rate (row 1 of Table 4) are virtually equal to the correlation between the Mexican stock returns and those exchange rates (row 3) suggesting that the Canadian and Mexican stock returns and exchange rates have a symmetrical relation.

Finally, we consider the estimated conditional correlation coefficients associated with changes in the three member countries' bilateral foreign exchange rates in Table 5. The estimated correlation between changes in MXN/CAD and CAD/USD $\left(\rho_{12}\right)$ is negative and statistically significant suggesting that a depreciation (appreciation) of the Mexican peso relative to the Canadian dollar has a statistically significant correlation with an appreciation (depreciation) of the Canadian dollar relative to the US dollar. On the other hand, the estimated conditional correlation between changes in MXN/CAD and MXN/USD $\left(\rho_{13}\right)$, and between MXN/USD and CAD/USD $\left(\rho_{23}\right)$ are positive although the former $\left(\rho_{13}\right)$ is not statistically significant.

To summarize, there appears to be co-movement between the three equity markets, in line with the findings of previous literature (e.g., Panton et al. 1976). The Canadian and Mexican stock market are more closely related to each other than either one is correlated with the U.S. market. Finally, all three stock markets are negatively correlated with bilateral exchange rates.

\section{c. Dynamic Conditional Correlations}

A drawback of conditional correlation is that it assumes the conditional covariance is proportional to the product of conditional standard errors, thus making the conditional 
correlation constant. In practice, this may not be the case. Engle (2002) and Tse and Tsui (2002) developed models with time-varying conditional correlations known as dynamic conditional correlation (DCC) models. Engle's DCC model uses conditional mean and variance equations similar to those in Equations (1) and (2) of the previous section but expresses the conditional correlation, $\rho$, as follows:

$$
\rho_{t}=\left[Q_{t} \odot I_{N}\right]^{-1 / 2} Q_{t}\left[Q_{t} \odot I_{N}\right]^{-1 / 2}
$$

where,

$$
Q_{t}=(1-\alpha-\beta) Q+\alpha Z_{t-1} Z_{t-1}^{\prime}+\beta Q_{t-1}
$$

And where $\odot$ is the Hadmard product of two matrices, $I_{N}=E\left[Z_{t}^{\prime} Z_{t}\right]$, and $Q$ is the sample covariance matrix of $Z_{t}$. An advantage of Engle's formulation of DCC is its simplicity as the correlation structure is determined by the two parameters, $\alpha$ and $\beta$, in Equation 7 regardless of the dimension of the problem. ${ }^{6}$

Using the Information Matrix Test (Bera and Kim 1996), we tested the hypothesis that the conditional correlation coefficients reported in the previous subsection are constant. The test rejected the null hypothesis in all cases except for the correlations between the Mexican and U.S. stock market returns and between the U.S. stock market returns and changes in the CAD/USD exchange rate. Thus, we estimate Engle's DCC for the cases where the conditional correlation is not constant and plot the results in Figures 3-7.

\footnotetext{
${ }^{6}$ For a discussion of limitations of DCC see Caporin and McAleer (2013).
} 
Begin with the correlation coefficients between pairs of stock market returns. The first panel of Figure 3 indicates that, except for the recent months, the correlation between the Canadian and U.S. equity markets has had a slightly declining trend. The second panel of Figure 3 shows that the correlation between the Canadian and Mexican stock markets fluctuates around a trend whose slope alternates in sign.

Turning to the correlation between stock returns and exchange rates, Figure 4 shows that the correlation between the U.S. stock market return and changes in the MXN/USD exchange rate has had a changing trend that has been declining in the last two years of the sample period. The correlation of the Canadian equity market with the CAD/USD exchange rate depicted in the first panel of Figure 5 goes through periods of changing trends with a sharp rise in the last two-and-a-half years of the sample period. The second panel of that figure shows no clear trend between the Canadian stock market returns and the MXN/CAD exchange rate. The first panel of Figure 6 shows a changing trend in the correlation between the Mexican stock market and the MXN/USD exchange rate. Based on the second panel of this figure, there does not appear to be a discernable trend in the dynamic conditional correlation between the Mexican stock market returns and changes in the MXN/CAD exchange rate except for sharp declines in the second half of the 1990s and mid-2000s.

Figure 7 shows dynamic correlations between pairs of the bilateral exchange rates. The first panel of this figure shows no clear trend in the 1990s in the correlation between CAD/USD and MXN/USD, a declining trend is seen in early 2000s until about 2002-2004 followed by a rising trend until recently and then a sharp decline in the past two years or so of the sample period. According to the second panel of Figure 7, a slightly negative trend is visible in the 
correlation between the CAD/USD and MXN/CAD exchange rates until 2008, which turns positive until 2012 and then it begins to decline. The third panel of this figure does not reveal a visible trend in the correlation between the MXN/USD and MXN/CAD exchange rates.

\section{Comparison of the Effects of NAFTA with CUSFTA}

In this section, we attempt to determine the effect of expanding the Canada - U.S. free trade agreement to include Mexico, an emerging economy. First, we compare the Canadian and U.S. stock markets and the CAD/USD exchange rate before and during CUSFTA. Next, we compare the CUSFTA results with those from NAFTA reported in the previous section.

Table 6 contains descriptive statistics on average daily returns to investing in the Canadian and U.S. stock markets and changes in the CAD/USD exchange rate before CUSFTA (January 3 , 1977 - December 31, 1988) and during CUSFTA (January 3, 1989 - December 31, 1993). Comparison of the two sets of results indicates that, while average returns for investing in the U.S. stock market increased during CUSFTA, it declined substantially for the Canadian stock market. What is more, during CUSFTA, USD appreciated against CAD. Based on the standard deviations, both equity markets experienced reduced historical volatility during CUSFTA, but the CAD/USD exchange rate became somewhat more volatile in this period.

We now repeat the exercise we performed in Section 5 where we assessed the effects of NAFTA for CUSFTA, and compare the results with those reported in Section 5 to determine the effect of including Mexico in the FTA. We start with conditional mean equations that, as before, include a constant term and dummy variables for the recessions that took place during each of the two sub-periods. When estimating conditional variances and correlations before CUSFTA, 
we also include a dummy variable representing the appreciation of USD between 1980 and 1985 that led to the Plaza Accord in September of 1985. Once again, we estimate all equations using the t-distribution that has fatter tails than the normal distribution.

Table 7 reports the mean values of estimated conditional variances of returns to the Canadian and U.S. stock markets and changes in the CAD/USD exchange rate before CUSFTA, during CUSFTA, and since the formation of NAFTA in 1994. The figures in the first two rows show that during CUSFTA the mean value of the conditional variance of Canadian stock returns declined by more than $60 \%$, and that of U.S. stock returns decreased by about $36 \%$. In contrast, the mean value of the conditional variance of CAD/USD rose by more than $30 \%$ during CUSFTA. These findings are shown in Figures 8-11. All in all, it appears that CUSFTA had a stabilizing effect on the Canadian and U.S. equity markets but a destabilizing effect on the CAD/USD exchange rate.

The first two columns of Table 8 contain estimated conditional correlations between the Canadian and U.S. stock returns and between each of these returns and the rate of change of CAD/USD exchange rate. The results in the first column indicate that before CUSFTA, higher (lower) returns in one stock market was associated with higher (lower) returns in the other stock market $\left(\rho_{12}\right)$. In contrast, higher (lower) returns in either of these two equity markets was associated with lower (higher) CAD/USD exchange rate ( $\rho_{13}$ and $\left.\rho_{22}\right)$.

The results in the second column of Table 8, which pertain to the period when CUSFTA was in effect, reveal that, as in the period before CUSFTA, the conditional correlation between the two stock market returns was positive and statistically significant. It is interesting to note that the magnitude of this estimate is $20 \%$ smaller than in the pre-FTA period suggesting that 
CUSFTA reduced spillovers between the two markets. Considering the estimates of conditional correlations between the two stock markets and the CAD/USD exchange rate, in contrast to the period before CUSFTA, both estimates are now positive, but neither is statistically significant suggesting that CUSFTA eliminated the link between the two stock markets and the CAD/USD exchange rate.

We are now in a position to compare the effects of CUSFTA with those of NAFTA. Comparison of the results in the last two rows of Tables 7 indicates that NAFTA significantly reduced the volatility of stock returns in Canada and the U.S. as the conditional variance of the Canadian stock returns declined by $53 \%$ and that of the U.S. decreased by $77 \%$ relative to the CUSFTA period. The CAD/USD exchange rate also benefited from NAFTA as its conditional variance declined from 0.83 during CUSFTA to 0.309 during NAFTA, a decrease of $63 \%$. Thus, the overall risk measured in terms of volatility of equity markets declined in both countries as did the risk of changes in the CAD/USD exchange rate.

Comparing the estimated conditional correlations during CUSFTA and NAFTA in columns (2) and (3) of Table 8 shows that the correlation between the Canadian and U.S. stock markets $\left(\rho_{12}\right)$ declined during NAFTA relative to CUSFTA. Further, the negative correlation between each of these two stock markets and the CAD/USD exchange rate ( $\rho_{12}$ and $\rho 23$ ) that had disappeared during CUSFTA is restored during NAFTA.

\section{Summary and Conclusions}

In this paper, we used a series of GARCH models and daily data to investigate the effect of the Canada - U.S. FTA as well as NAFTA on the volatility of and the relationship between the 
returns to investing in stock markets and changes in bilateral exchange rates of member countries. For each country in the sample, we estimated the conditional variance of returns and the rate of change of exchange rates before CUSFTA, during CUSFTA, and since NAFTA. We also estimated conditional correlations between pairs of stock returns and between stock returns and exchange rate variations to determine whether they increased, decreased, or were unaffected by CUSFTA and NAFTA.

The results presented in this paper suggest that during the period between the inception of NAFTA in January 1994 and July 2014, the Mexican stock market was more volatile than the other stock and bilateral currency exchange markets. We also found that in this period, the exchange rate of the Mexican peso against both the U.S. and Canadian dollars was much more volatile than the CAD/USD exchange rate.

Evidence also suggests that all three stock markets are positively correlated with each other with the U.S. market being much less correlated with the Canadian and Mexican stock markets than the latter two markets are correlated with each other. We found evidence of a negative relationship between the stock and bilateral currency markets. This relationship is statistically significant except for the U.S. equity market when paired with an exchange rate that involves the Mexican peso.

An objective of this research was to determine the effect of free trade agreements on the volatility of stock returns and exchange rates, and on the relationship between the two variables. Specifically, our aim was to investigate how the inclusion of Mexico, an emerging economy with lesser developed financial markets in an existing FTA between two developed economies with highly efficient financial markets would impact the latter two national markets. 
Our empirical findings indicate that CUSFTA that preceded NAFTA had a stabilizing effect on the Canadian and U.S. equity markets while increasing the volatility of CAD/USD exchange rate. We also found that NAFTA further reduced the two stock markets' volatility compared to CUSFTA. However, unlike CUSFTA, NAFTA also reduced the volatility of CAD/USD exchange rate. All in all, then, it appears that free trade agreements may have the potential of stabilizing members' financial markets. These results are consistent with the notion that deepening integration that enhances trade flows and cross-border capital flows can have beneficial stabilizing effects, depending on the correlation between a risky asset (here, Mexican financial market instruments) and less risky assets (Canada and U.S. financial market instruments), via crossborder portfolio diversification.

In general, our results imply that FTAs may have stabilizing effects on key markets such as foreign exchange and stock markets. With this in mind, the practical aspects of our conclusion are important in light of recent attempts to renegotiate NAFTA. A misplaced focus on trade balances overlooks the beneficial stabilizing effects of NAFTA that emanate from greater current and capital-account integration. Rather than deepening and widening NAFTA, announcements to withdraw from a FTA, renegotiate a FTA, or renegotiations of an existing FTA collapsing may have destabilizing effects on currency and stock markets, especially for smaller economies not broadly integrated beyond the regional agreement. 


\section{References}

Aggarwal (1998), Industry Differences in NAFTA Impact on Valuation of US Companies, International Review of Financial Analysis, 7(2), 137-153.

Aggarwal, R. and N. A. Kyaw (2005), Equity Market Integration in the NAFTA Region: Evidence from Unit Root and Cointegration Tests, International Review of Financial Analysis, 4, 393406.

Ajayi, R. A. and M. Mougoué (1996), On the Dynamic Relation between Stock Prices and Exchange Rates, Journal of Financial Research, XIX (2), 193-207.

Arndt, Sven (1996), Review Essay: North American Free Trade: An Assessment, Open Economies Review, 7, 77-92.

Baier, S. L. and J.H. Bergstrand (2007), Bonus Vetus OLS: A Simple Method for Approximating International Trade-Cost Effects Using the Gravity Equation, Journal of International Economics, 77(1), 77-85.

Bahmani-Oskooee, M. and A. Sohrabian (1992), Stock Prices and the Effective Exchange Rate of the Dollar, Applied Economics, 24 (4), 459-464.

Basu, Parantap, and Matthew R. Morey (2005), "Trade Opening and the Behavior of Emerging Stock Market Prices," Journal of Economic Integration, 20(1), 68-92.

Bera, A. K. and S. Kim (1996), Testing Constancy of Correlation with an Application to International Equity Returns, the University of Illinois at Urbana-Champaign.

Bodart, V. and P. Reding (1999), Exchange Rate Regime, Volatility and International Correlations on Bond and Stock Markets, Journal of International Money and Finance, 18, 133-151.

Bolerslev, T., Engle, R. F., and J. M. Woodridge (1988), A Capital Asset Pricing Model with TimeVarying Covariances, Journal of Political Economy, 96(1), 116-131.

Bollerslev, T. (1990), Modelling the Coherence in Short-Run Nominal Exchange Rates: A Multivariate Generalized Arch Model, The Review of Economics and Statistics, 72(3), 498505.

Calvo-Pardo, H., Freund, C., and E. Ornelas (2009), The ASEAN Free Trade Agreement: Impact on Trade Flows and External Trade Barriers.

Caporin, M. and M McAleer (2013), Ten Things You Should Know about the Dynamic Conditional Correlation Representation, Econometrics, 1, 116-126.

Daniels, J.P., O'Brien, P. and M. von der Ruhr, (2015), Bilateral Tax Treaties and US Foreign Direct Investment Financing Modes, International Tax and Public Finance, 22(6), 999-1027.

Darrat, A. F. and M. Zhong (2005), Equity Market Linkage and Multinational Trade Accords: The Case of NAFTA, Journal of International Money and Finance, 24, 793-817.

Du, D., and O. Hu (2012a), Exchange Rate Risk in the U.S. Stock Market, Journal of International Financial Markets, Institution and Money, 22, 137-150.

(2012b), Foreign Exchange Volatility and Stock Returns, Journal of International Financial Markets, Institutions and Money, 22, 1202-1216.

Eissa, M. A., Chortareas, G., and A. Cipollini (2010), Stock Returns and Exchange Rate Volatility Spillovers in the MENA Region, Journal of Emerging Market Finance, 9(3), 257-284.

Engle, R. F. (2002), Dynamic Conditional Correlation: A Simple Class of Multivariate Generalized Autoregressive Conditional Heteroskedasticity Models, Journal of Business and Economic Statistics, 20(3), 339-350. 
Engle, R. F. and K. F. Kroner (1995), Multivariate Simultaneous Generalized ARCH, Econometric Theory, 11(1), 122-150.

Eun, C. S. and S. Shim (1989), International Transmission of Stock Market Movements, Journal of Financial and Quantitative Analysis, 24(2), 241.

Ewing, B. T., Payne, J. E., and C. Sowell (1999), NAFTA and North American Stock Market Linkages: An Empirical Note, North American Journal of Economics and Finance, 10, 443451.

(2001). Transmission of Conditional Stock Return Volatility across North American Markets: Evidence from Pre- and Post-NAFTA. The International Trade Journal, XV(4), 409 427.

Feinberg, S. E. and M. P. Keane (2001), U.S.-Canada Trade Liberalization and MNC Production Location, Review of Economics and Statistics, 83(1), 118-132

Gallagher, K., Anderson, S. and A. Viterbo (2013), Capital Flow Management and the TransPacific Partnership Agreement, G-24 Policy Brief No. 79.

Hamao, Y., Masulis, R. W., and V. Ng (1990), Correlations in Price Changes and Volatility across International Stock Markets. The Review of Financial Studies, 3(2), 281-307.

Hanson, R. C. and M. H. Song (1998), Shareholder Wealth Effects of Free Trade: U.S. and Mexican Stock Market Response to NAFTA, International Review of Economics and Finance, $7(2), 209-224$.

Hau, Harald (2002), "Real Exchange Rate Volatility and Economic Openness: Theory and Evidence," Journal of Money, Credit, and Banking, 34(3), 611-630.

Hogan, K., and J. Sultan (1994), Foreign Exchange Market Reaction to the U.S.-Canada Free Trade Agreement, The Journal of Financial Research, XVII(4), 539-549.

Hutchinson, M. and F. Nourzad (2004), An Empirical Inquiry into the Structure of International Stock Market Interdependence, Journal of Applied Economics, III(4),35-46.

Kanas, A. (2002), Is Exchange Rate Volatility Influenced by Stock Return Volatility? Evidence from the US, the UK, and Japan, Applied Economics Letters, 9(8), 501-503.

Kennedy, K. and F. Nourzad (2016), "Exchange Rate Volatility and its Effect on Stock Market Volatility," International Journal of Human Capital and Urban Management, 1(1), 37-46.

Kim, Soyoung, Kim, Sunghyun, and Y. Wang (2004), Macroeconomic Effects of Capital Account Liberalization: the Case of Korea, Review of Development Economics, 8(4), 624-639.

Klein, L., and Alfredo Coutiño (1996), The Mexican Financial Crisis of December 1994 and Lessons to Be Learned, Open Economies Review, 7(1), 501-510.

Krishnapilla, S. and H. Thompson (2011), Exchange Rates, Free Trade Agreement and Bilateral Trade Valances of Sri Lanka, Indian Journal of Economics and Business, 10(2-3), 163-171.

Lee, S. J. (2009), Volatility Spillover Effects Among Six Asian Countries and the United States, Applied Economics Letters,16(5), 501-508.

Manchester, Joyce, and Warwick McKibbin (1995), The Global Macroeconomics of NAFTA, Open Economies Review, 6(3), 203-223.

Marmolejo, A. L. (2011), Effects of a Free Trade Agreement on the Exchange Rate Pass-through to Import Prices, Review of International Economics, 19(3), 475-493.

Mun, K.C. (2007), Volatility and Correlation in International Stock Markets and the Role of Exchange Rate Fluctuations, International Financial Markets, Institutions and Money, 17, 25-41. 
Nezerwe, Y. (2014), Southern African Development Community Free Trade Agreement Impact on South Africa Stock Returns, Global Journal of Business Research, 8(1), 57-63.

Nieh, C. C. and C. F. Lee (2001), Dynamic Relationship Between Stock Prices and Exchange Rates for G-7 Countries, The Quarterly Review of Economics and Finance, 41, 477-490.

Panton, D. B., Lessig, P. V., and M. O. Joy (1976), Comovements of International Equity Markets: A Taxonomic Approach, Journal of Financial and Quantitative Analysis, 11(3), 415-432.

Peter, Alexandra (2012), Bilateral Trade, Openness, and Asset Holdings, Open Economies Review, 23, 713-740.

Phengpis, Chanwit, and Peggy E. Swanson (2006), "Portfolio Diversification Effects of Trading Blocks: The Case of NAFTA," Journal of Multinational Financial Management, 16, 315-331.

Reinhart, C. M. and K. S. Rogoff (2009), This Time is Different: Eight Centuries of Financial Folly, Princeton: Princeton University Press.

Rodriguez, P. (2003), Investors Expectations and NAFTA, Review of International Economics, 11(1), 206-218.

Tabak, B. M. (2006) The Dynamic Relationship between Stock Prices and Exchange Rates: Evidence from Brazil, International Journal of Theoretical and Applied Finance, 9(8), 13771396.

Taylor, Mark P. and lan Tonks, 1989, "The Internationalisation of Stock Market Returns and the Abolition of U.K. Exchange Rate Control," The Review of Economics and Statistics, 71(2), 332-336.

Tse, Y. K. and A. K. Tsui (2002), A Multivariate Generalized Autoregressive Conditional Heteroscedasticity Model with Time-Varying Correlations, Journal of Business and Economic Statistics, 20(3), 351-362.

Walid, C., Chaker, A., Masood, O., and J. Fry (2011), Stock Market Volatility and Exchange Rates in Emerging Countries: A Markov-state Switching Approach, Emerging Markets Review, 12, 272-292.

U.S. and Canadian Governments (1988), The Canada - US Free Trade Agreement.

Yang, S. Y. and S. C. Doong (2004), Price and Volatility Spillovers between Stock Prices and Exchange Rates: Empirical Evidence from the G-7 Countries, International Journal of Business and Economics, 3(2), 139-153.

Zhao, H. (2010) Dynamic Relationship between Exchange Rate and Stock Price: Evidence from China, Research in International Business and Finance 24, 103-112. 
TABLE 1

Daily Stock Market Returns and Changes in Bilateral Exchange Rates During NAFTA (1/3/1994 - 7/22/2014)

\begin{tabular}{lccc}
\hline & $\begin{array}{c}\text { Stock Market } \\
\text { Canada }\end{array}$ & $\begin{array}{c}\text { Stock Market } \\
\text { U.S. }\end{array}$ & Stock Market Mexico \\
\hline Mean & 0.026 & 0.029 & 0.057 \\
Std. Dev. & 1.116 & 1.227 & 1.602 \\
\hline & Currency Market & Currency Market & Currency Market \\
& CAD/USD & MXN/CAD & MXN/USD \\
\hline Mean & -0.004 & 0.033 & 0.0290 \\
Std. Dev. & 0.532 & 0.904 & 0.909 \\
\hline
\end{tabular}

TABLE 2

Average Estimated Conditional Variances of Daily Stock Market Returns And Changes in Bilateral Exchange Rates

During NAFTA (1/3/1994 - 7/22/2014)

\begin{tabular}{ccc}
\hline $\begin{array}{c}\text { Stock Market } \\
\text { Canada }\end{array}$ & $\begin{array}{c}\text { Stock Market } \\
\text { U.S. }\end{array}$ & $\begin{array}{c}\text { Stock Market } \\
\text { Mexico }\end{array}$ \\
\hline 0.127 & 0.150 & 0.299 \\
$\begin{array}{c}\text { Currency Market } \\
\text { CAD/USD }\end{array}$ & $\begin{array}{c}\text { Currency Market } \\
\text { MXN/CAD }\end{array}$ & $\begin{array}{c}\text { Currency Market } \\
\text { MXN/USD }\end{array}$ \\
\hline 0.283 & 0.692 & 0.706 \\
\hline
\end{tabular}

TABLE 3

Estimates of Conditional Correlations between Stock Market Returns

During NAFTA (1/3/1994 - 7/22/2014)

\begin{tabular}{cc} 
(p-values in parentheses) \\
\hline$\rho_{12}$ & 0.144 \\
& $(0.00)$ \\
$\rho_{13}$ & 0.111 \\
& $(0.00)$ \\
$\rho_{23}$ & 0.526 \\
& $(0.00)$ \\
\hline
\end{tabular}

$\rho_{12}=$ Conditional correlation between U.S. and Canadian stock returns

$\rho_{13}=$ Conditional correlation between U.S. and Mexican stock returns

$\rho_{23}=$ Conditional correlation between Canadian and Mexican stock returns 
TABLE 4

\begin{tabular}{cccc}
$\begin{array}{c}\text { Estimates of Conditional Correlations Between Stock Market Returns } \\
\text { and Changes in Bilateral Exchange Rates } \\
\text { During NAFTA (1/3/1994 - 7/22/2014) } \\
\text { (p-values in parentheses) }\end{array}$ \\
\hline & $\begin{array}{c}(1) \\
\text { CAD/USD }\end{array}$ & MXN/USD & MXN/CAD \\
\hline CAN Stck. Mrkt. & -0.252 & -0.357 & -0.136 \\
& $(0.00)$ & $(0.00)$ & $(0.00)$ \\
U.S. Stck. Mrkt. & -0.044 & -0.019 & -0.09 \\
& $(0.01)$ & $(0.27)$ & $(0.59)$ \\
MEX Stck. Mrkt. & -0.250 & -0.351 & -0.118 \\
& $(0.00)$ & $(0.00)$ & $(0.00)$ \\
\hline
\end{tabular}

TABLE 5

Estimates of Conditional Correlations between Changes in Pairs of Bilateral Exchange Rates

During NAFTA (1/3/1994 - 7/22/2014)

(p-values in parentheses)

$\begin{array}{lc}\rho_{12} & -0.501 \\ & (0.00) \\ \rho_{13} & 0.681 \\ & (0.27) \\ \rho_{23} & 0.289 \\ & (0.00)\end{array}$

$\rho_{12}=$ Conditional correlation between rate of change of MXN/CAD exchange rate and rate of change of CAD/USD exchange rate

$\rho_{13}=$ Conditional correlation rate of change of MXN/CAD exchange rate and rate of change of MXN/USD exchange rate

$\rho_{23}=$ Conditional correlation between rate of change of MXN/USD exchange rate and rate of change of CAD/USD exchange rate 
TABLE 6

Sample Mean Values and Standard Deviations of Daily Market Returns

\begin{tabular}{lccc} 
& & \multicolumn{2}{c}{$\begin{array}{c}\text { Before CUSFTA } \\
\text { (1/3/1977 - 12/31/1988) }\end{array}$} \\
\cline { 3 - 4 } & $\begin{array}{l}\text { Stock Market } \\
\text { Canada }\end{array}$ & $\begin{array}{c}\text { Stock Market } \\
\text { U.S. }\end{array}$ & $\begin{array}{c}\text { Currency Market } \\
\text { CAD/USD }\end{array}$ \\
\hline Mean & 0.040 & 0.032 & 0.006 \\
Std. Dev. & 0.865 & 1.049 & 0.239 \\
& & \multicolumn{3}{c}{} \\
& & During CUSFTA \\
& & (1/3/1989 - 12/31/1993) \\
\cline { 3 - 4 } & Stock Market & Stock Market & Currency Market \\
Canada & U.S. & CAD/USD \\
Mean & 0.022 & 0.043 & 0.008 \\
Std. Dev. & 0.543 & 0.806 & 0.278 \\
\hline
\end{tabular}

TABLE 7

Average Estimated Conditional Variances of Daily Stock Market Returns and Exchange Rates

Before CUSFTA, During CUSFTA, and During NAFTA

(p-values in parentheses)

\begin{tabular}{lccc}
\hline & $\begin{array}{c}\text { Stock Market } \\
\text { Canada }\end{array}$ & $\begin{array}{c}\text { Stock Market } \\
\text { U.S. }\end{array}$ & $\begin{array}{c}\text { Currency Market } \\
\text { CAND/USD }\end{array}$ \\
\hline Before CUSFTA & 0.739 & 1.032 & 0.60 \\
During CUSFTA & 0.270 & 0.655 & 0.83 \\
During NAFTA & 0.127 & 0.150 & 0.309 \\
\hline
\end{tabular}

TABLE 8

Estimates of Conditional Correlations

Before CUSFTA, During CUSFTA, and During NAFTA

(p-values in parentheses)

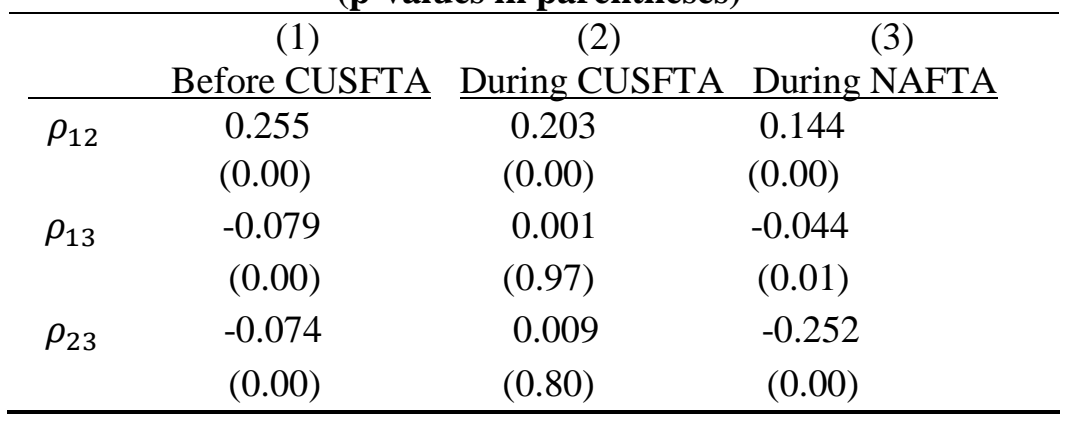

$\rho_{12}=$ Conditional correlation between Canadian and U.S. stock returns

$\rho_{13}=$ Conditional correlation between returns to Investing in U.S. stocks and rate of change of

CAD/USD exchange rate

$\rho_{23}=$ Conditional correlation between returns to investing in Canadian stocks and rate of change of

CAD/USD exchange rate 
Figure 1

Conditional Variances of Stock Returns During NAFTA

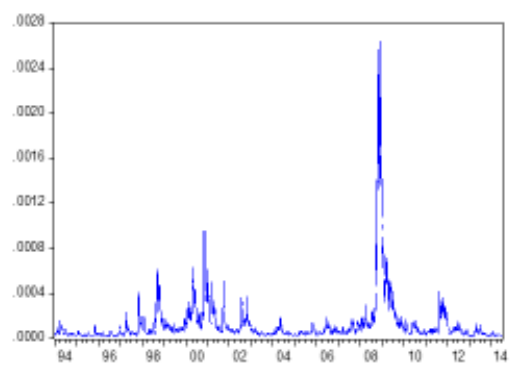

Canada

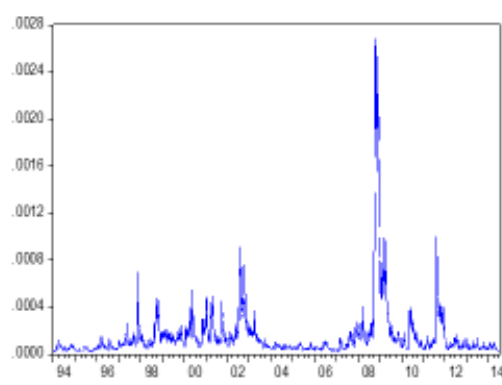

U.S.

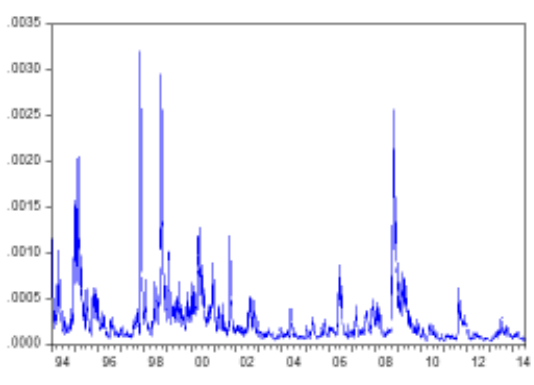

Mexico

Figure 2

Conditional Variances of Changes in Bilateral Exchange Rates During NAFTA

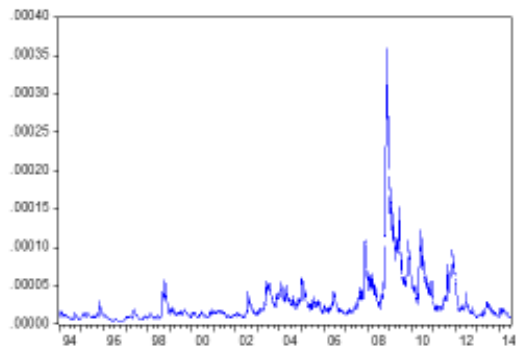

CAD/USD

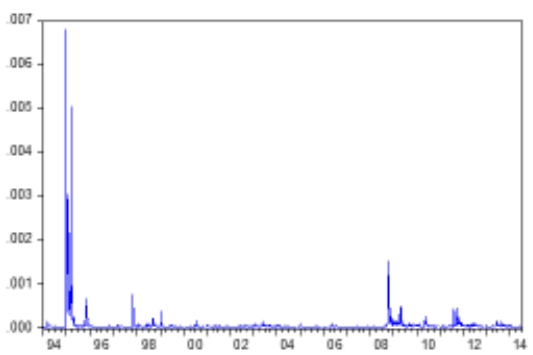

MXN/USD

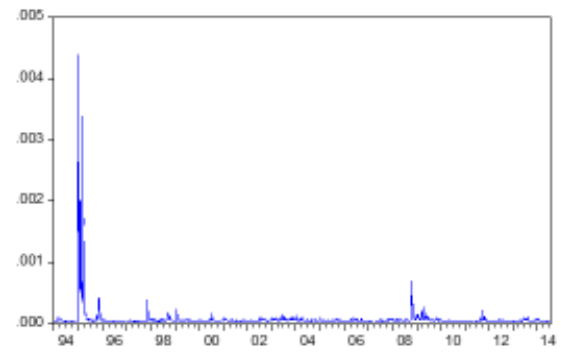

MXN/CAD 
Figure 3

Dynamic Conditional Correlation between Stock Returns During NAFTA

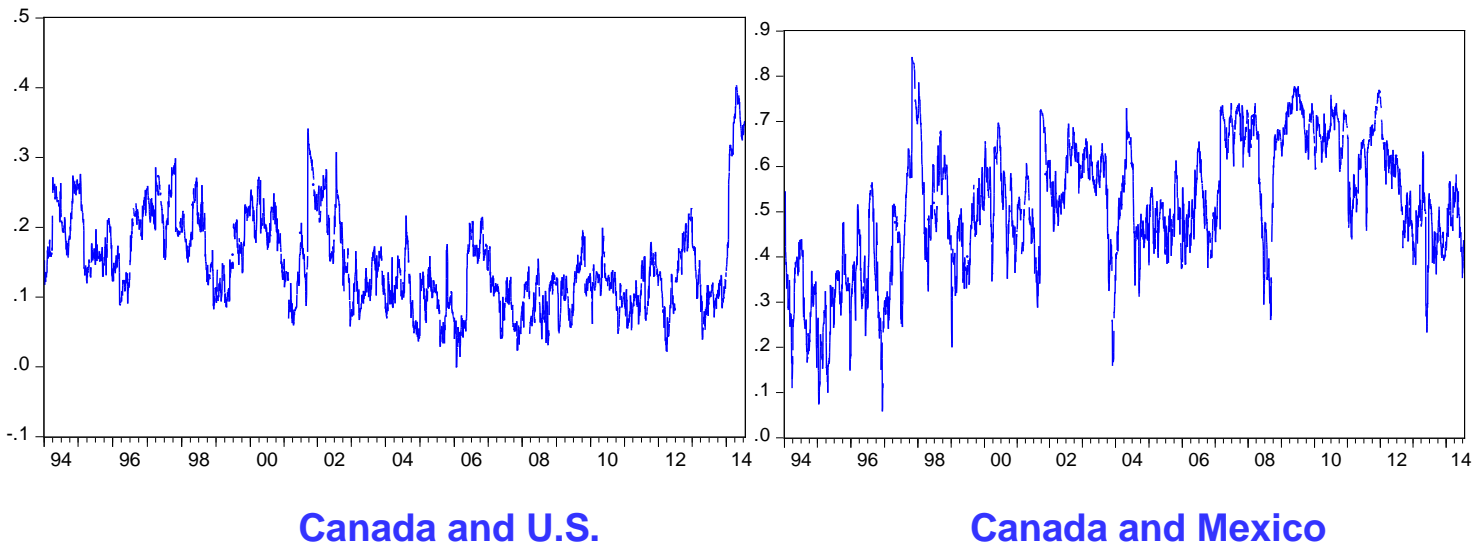

Figure 4

Dynamic Conditional Correlation between

U.S. Stock Returns and Changes in MXN/USD Exchange Rate

During NAFTA

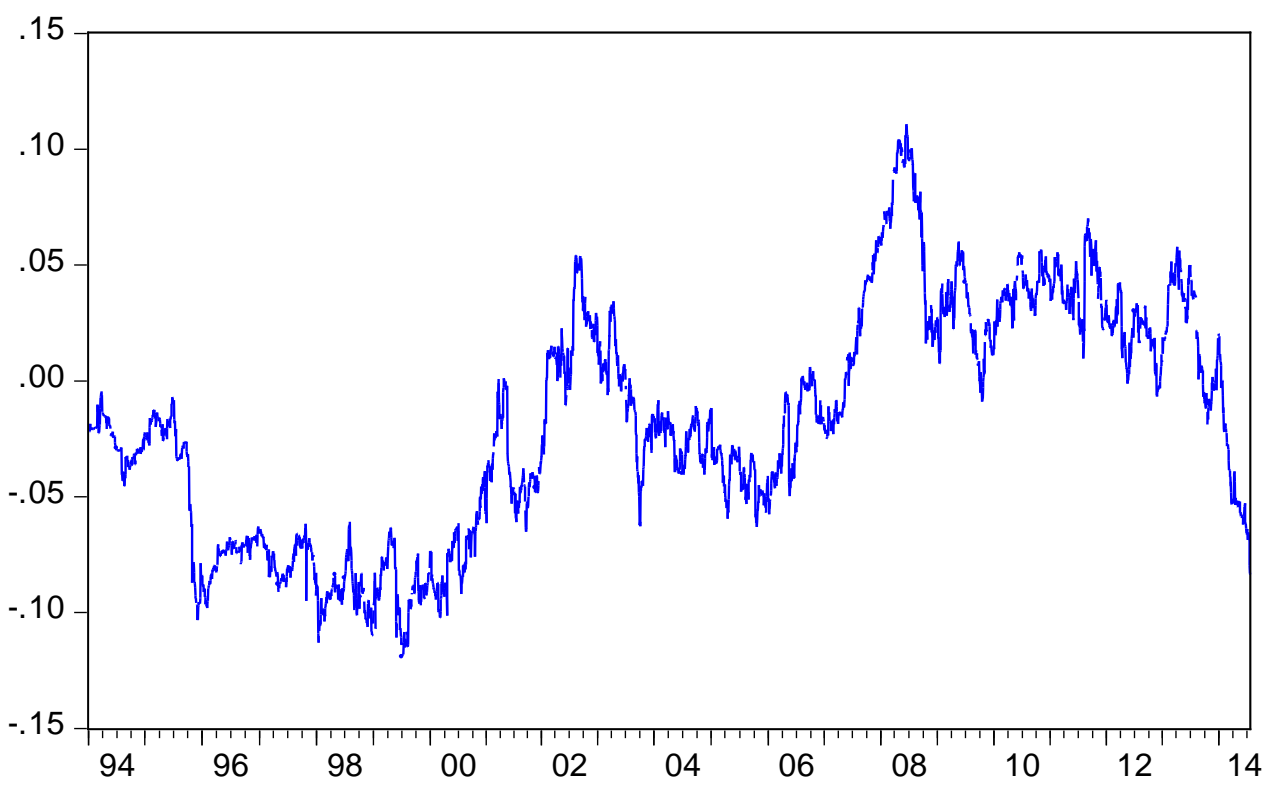


Figure 5

Dynamic Conditional Correlation

Canadian Stock Returns and Changes in CAD/USD and MXN/CAD Exchange Rates

During NAFTA
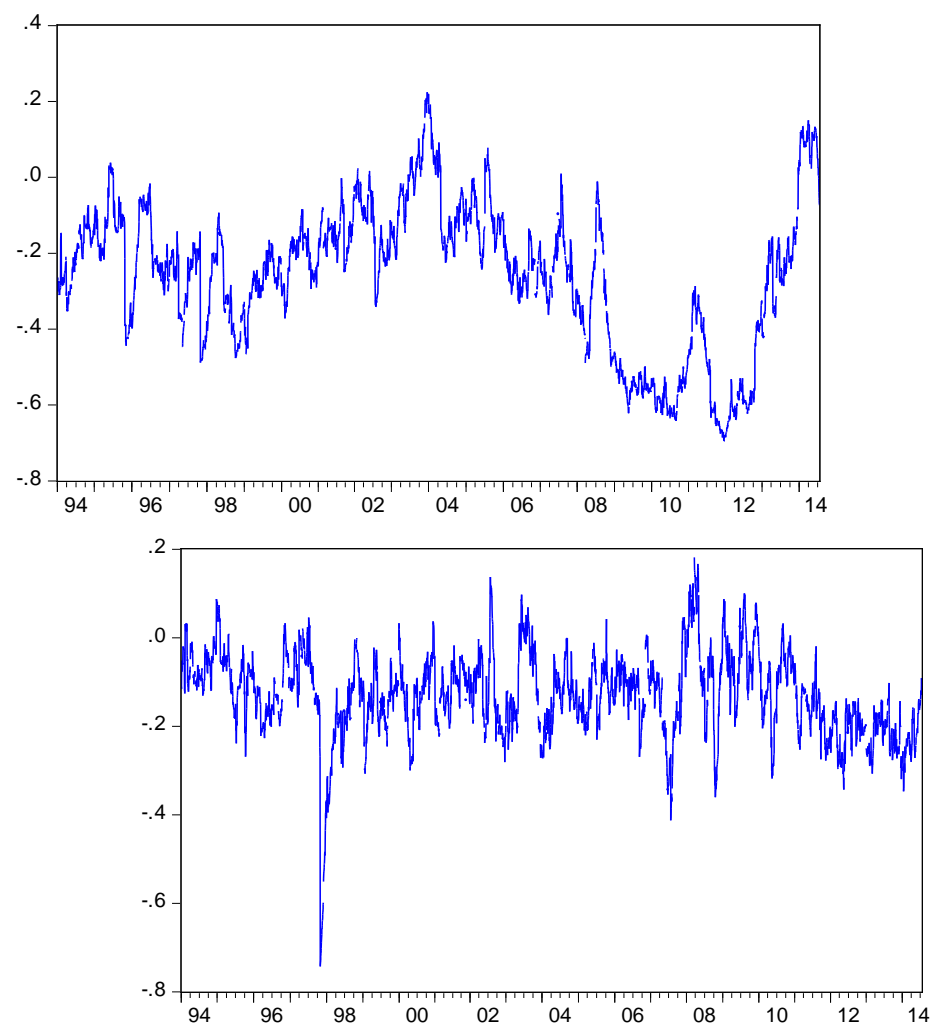

CAD/USD

MXN/CAD

Figure 6

Dynamic Conditional Correlation

Mexican Stock Returns and Changes in MXN/USD and MXN/CAD Exchange Rates During NAFTA

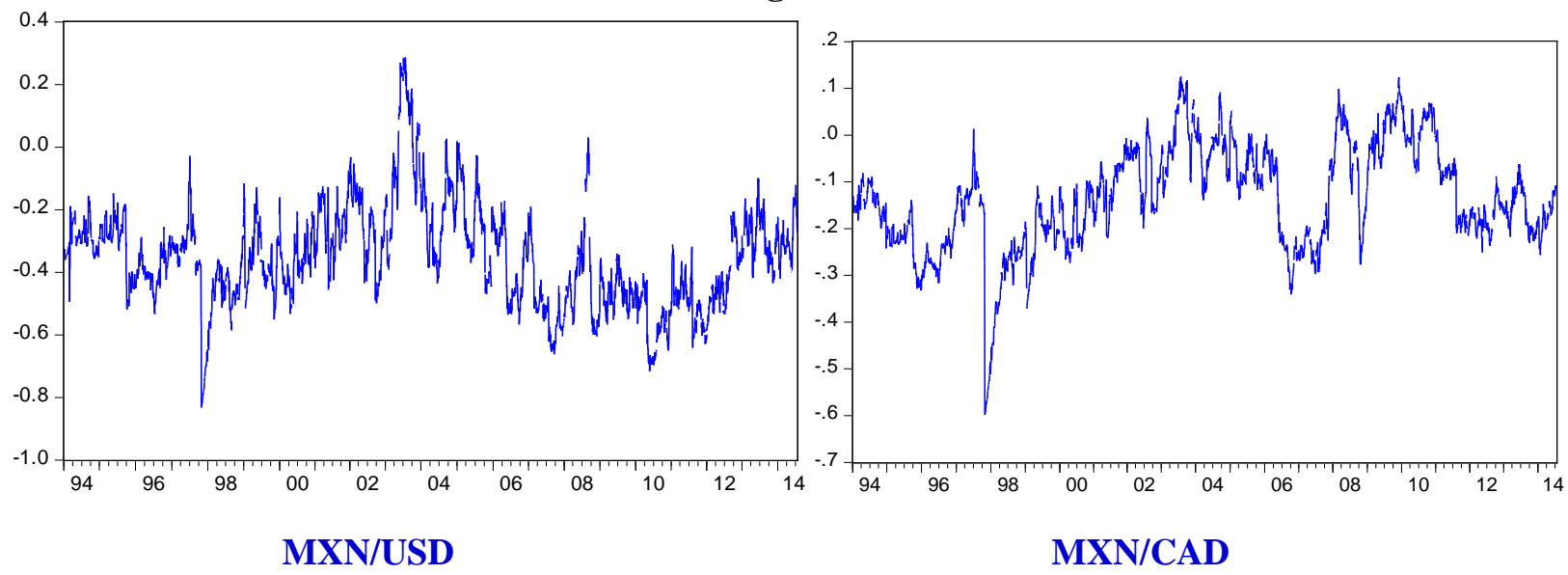


Figure 7

Dynamic Conditional Correlation between

Changes in CAD/USD Exchange Rate and Changes in MXN/USD Exchange Rate

During NAFTA

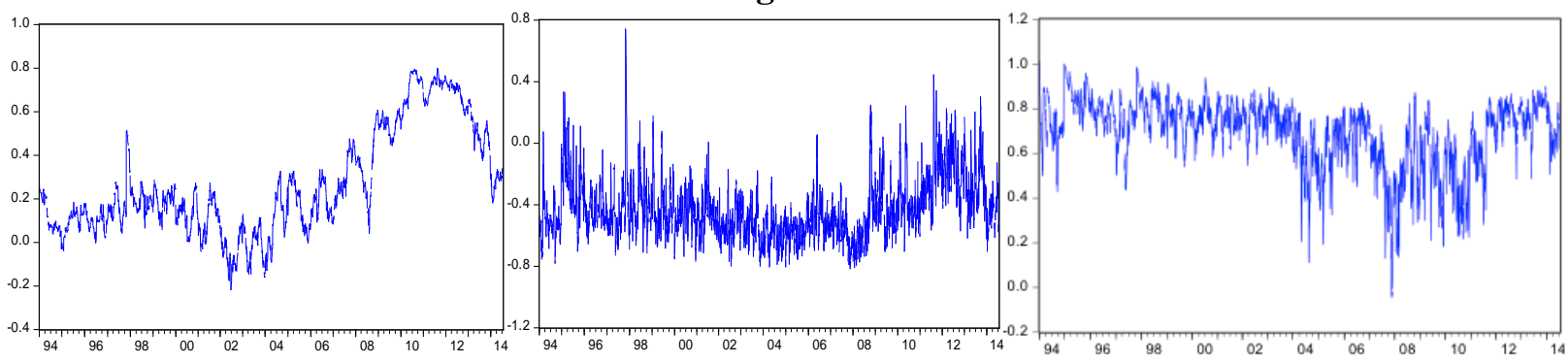

CAD/USD and MXN/USD CAD/USD and MXN/CAD MXN/USD and MXN/CAD

Figure 8

Conditional Variances of Stock Returns Before CUSFTA

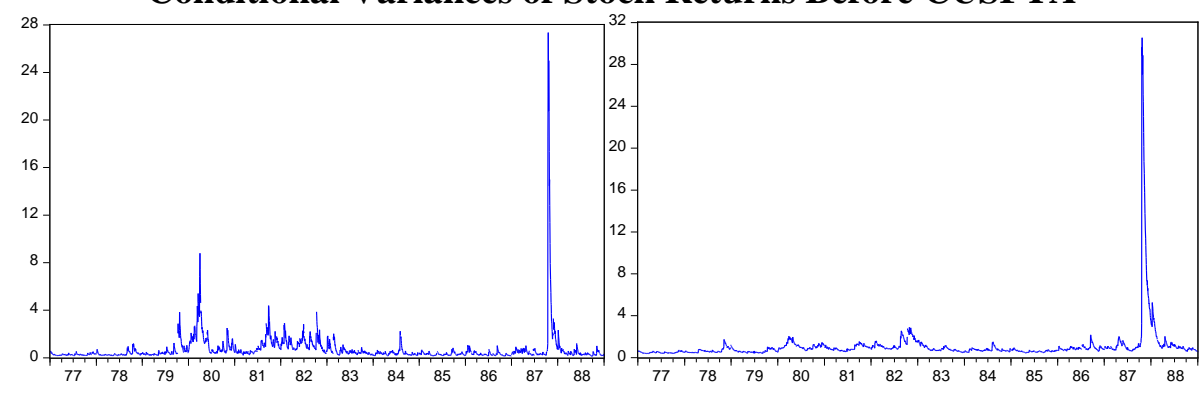

Canada

U.S.

Figure 9

Conditional Variance of Changes in CAD/USD Exchange Rate

Before CUSFTA

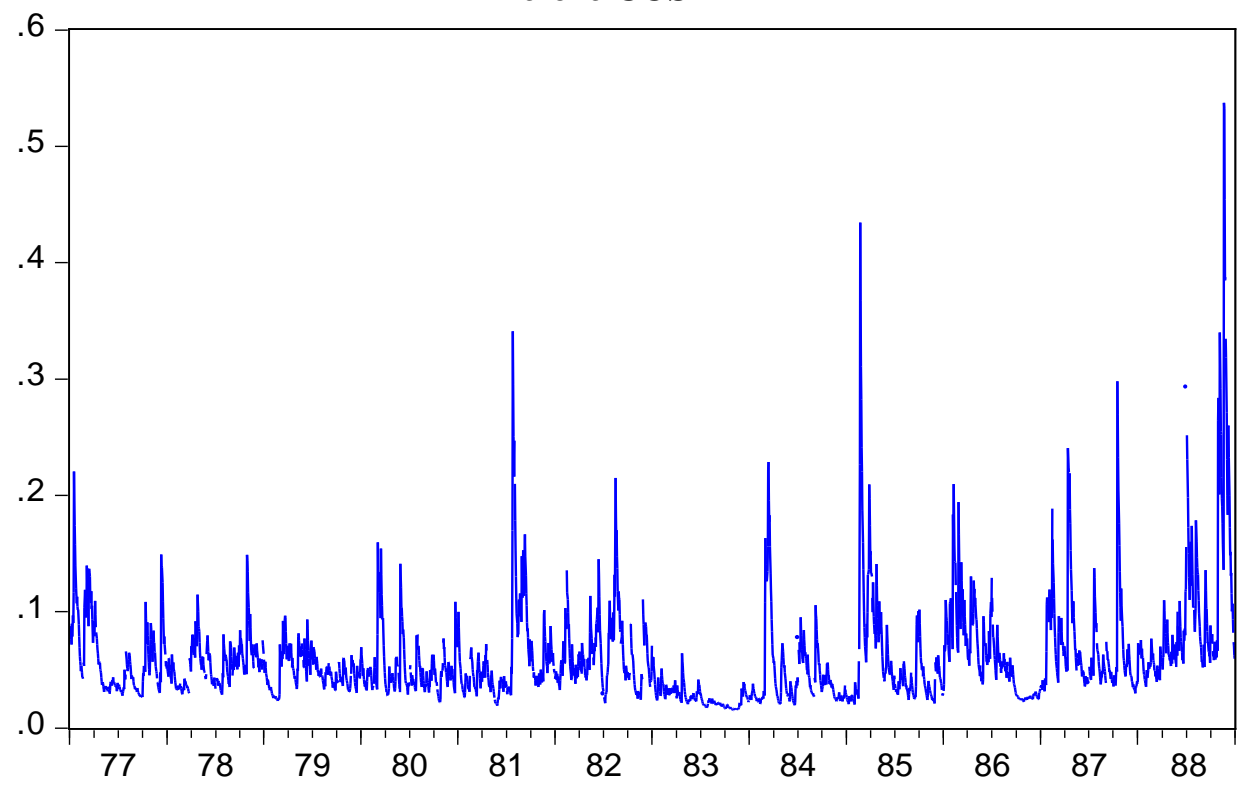




\section{Figure 10}

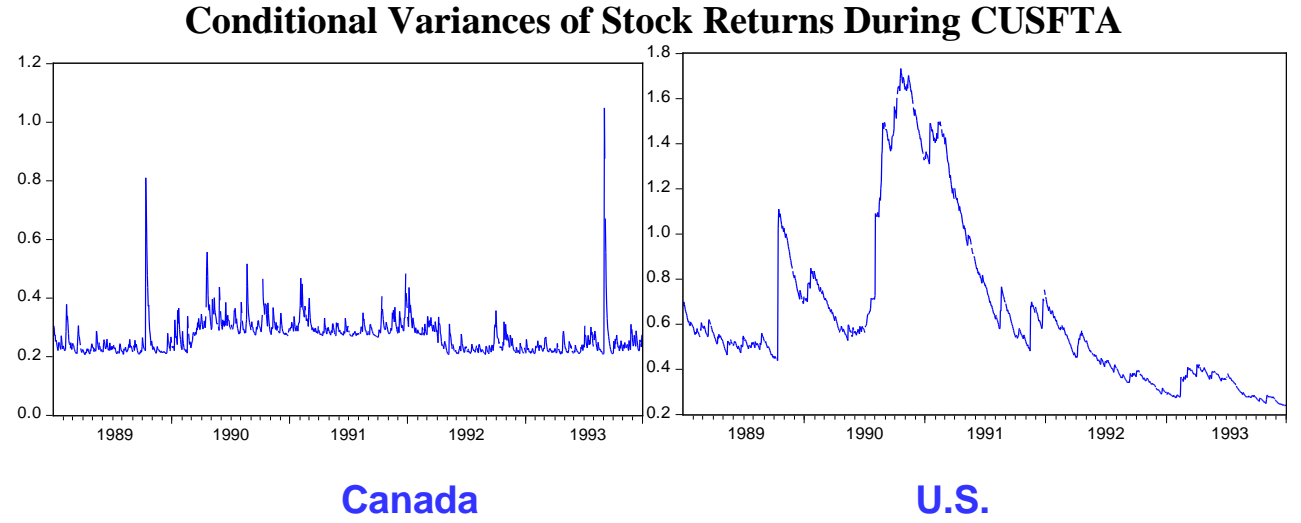

Figure 11

Conditional Variance of Changes in CAD/USD Exchange Rate During CUSFTA

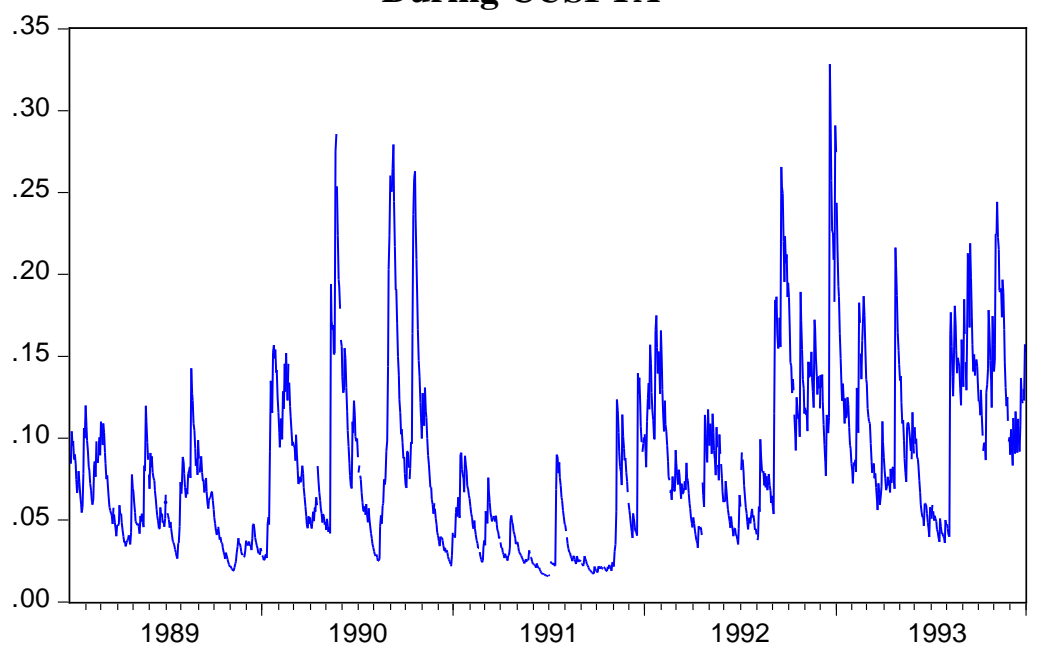

